Рекомендована д. фрармац. наук, проф. Д. І. Дмитрієвським

УДК 615.453.035/.07:664.144

DOI 10.11603/2312-0967.2018.1.8700

\title{
ГУМКИ ЖУВАЛЬНІ ЛІКУВАЛЬНІ: ПРИЗНАЧЕННЯ, ТЕХНОЛОГІЯ І АНАЛІЗ
}

\author{
() В. М. Коваль ${ }^{1}$, А. І. Денис ${ }^{2}$, Т. А. Грошовийㄹ, Л. В. Вронська²
}

Вінницький національний медичний університет імені М. І. Пирогова ${ }^{1}$

ДВНЗ «Тернопільський державний медичний університет імені І. Я. Горбачевського мО3 України»²

Koval_vm@ukr.net

\begin{abstract}
Мета роботи. Аналіз і систематизація даних літератури щодо призначення і класисрікації гумок жувальних лікувальних, їх технології, методів дослідження і показників якості.

Матеріали і методи. У роботі використано методи інорормаційного пошуку, аналізу даних літератури щодо лікарської форми - гумка жувальна лікувальна.

Результати й обговорення. Гумка жувальна лікувальна є зручною системою доставки лікарського засобу і може забезпечувати високу комплаєнтність пацієнта. Для виготовлення гумки жувальної лікувальної використовують метод плавлення; метод замороження, подрібнення і таблетування; метод прямого пресування. Фармакопейними показниками якості гумок є опис, ідентифрікація, середня маса, однорідність маси, однорідність вмісту, розчинення, мікробіологічна чистота, кількісне визначення. У процесі розробки складу і технології гумок набір фрармакотехнологічних показників і методик випробувань суттєво відрізняється від фармакопейних і включає визначення численних органолептичних властивостей, вивчення текстури інструментальними методами.

Висновок. Гумка жувальна лікувальна - це мобільна система доставки ліків, яка містить один або кілька активних інгредієнтів, що вивільняються шляхом жування. Розглянуто методи та особливості технології, фрармакотехнологічні показники і показники якості гумок жувальних лікувальних. Дана лікарська форма має переваги порівняно з традиційними системами доставки ліків, характеризується високим комплаєнсом. Серед трьох відомих методів отримання гумок, за рахунок появи готових основ промислового виробництва, все більшого застосування набуває метод прямого пресування.
\end{abstract}

Ключові слова: гумки жувальні лікувальні; призначення; переваги; недоліки; технологія; фрармако-технологічні показники; показники якості.

Вступ. Одним із важливих етапів створення нового лікарського засобу є вибір раціональної лікарської форми, яка часто визначає готовність пацієнта відповідально застосовувати ліки [1]. В якості зручної та перспективної системи доставки лікарських засобів через ротову порожнину з локальною або системною дією є гумка жувальна лікувальна. Дана лікарська форма є поєднанням еластичної не розчинної у воді основи, в яку поміщені інші інгредієнти. Гумка жувальна лікувальна призначена для жування впродовж певного періоду часу і, на відміну від жувальних таблеток, не призначена для проковтування.

Мета роботи - аналіз і систематизація даних літератури щодо призначення і класифрікації гумок жувальних лікувальних, їх технології, методів дослідження і показників якості.

Класифікація гумок жувальних лікувальних, їx переваги і недоліки. Гумки жувальні можуть бути покритими або непокритими оболонками [2]. Останні наносять 3 різною метою: щоб захистити активний фрармацевтичний інгредієнт (АФІ) від дії світла і воло- ги; щоб запобігти злипанню гумок у процесі зберігання; щоб помістити АФІ у склад оболонки тощо.

За локалізацією дії розрізняють гумки жувальні 3 місцевою та з системною дією [3]. Спочатку гумки жувальні лікувальні застосовували для лікування та профрілактики карієсу (фрторовмісні гумки жувальні), запальних захворювань ротової порожнини, покращення подиху та полегшення відмови від куріння (нікотиновмісні гумки жувальні). Сьогодні гумки жувальні набувають широко застосування не лише при лікуванні органів ротової порожнини, але й у фрармакотерапії системних захворювань. Зокрема, для лікування больового синдрому, ожиріння, ксеростомії, діабету або попередження синдромів захитування, нудоти і блювання [2, 4-6]. Є хороші перспективи одержання оральних лікарських фрорм інсуліну без інгібіторів фрерментів травлення, у вигляді гумки жувальної [7].

Системна дія активних речовин, що вивільняються $з$ цієї лікарської фрорми, може бути досягнута двома способами. У процесі жування активні компоненти гумки жувальної вивільняються в слину і ковта-

ISSN 2312-0967. Фармацевтичний часопис. 2018. № 1 
ються, потрапляючи у шлунок, а в подальшому всмоктуються у шлунково-кишковому тракті. В іншому випадку абсорбція АФІ відбувається через слизову оболонку порожнини рота. Останнє в окремих випадках є особливо важливим і значущим. Букальне всмоктування АФІ дозволяє уникнути впливу хлористоводневої кислоти і ферментів та першого проходження через печінку, може забезпечити високу біологічну доступність $[2,4]$ і навіть знизити терапевтичну дозу, а тому і запобігти проявам деяких побічних реакцій.

Гумка жувальна лікувальна має переваги порівняно 3 традиційними системами доставки ліків, серед яких [2, 4, 5, 8-13]:

1) швидкий початок дії. Так, ацетилсаліцилова кислота, дименгідринат, кофеїн, преднізолон, індометацин швидше вивільняються з гумок жувальних, ніж 3 таблеток чи капсул [8-10];

2) всмоктування АФІ відбувається через слизову оболонку ротової порожнини 3 подальшим потраплянням безпосередньо в системний кровотік, що дає можливість знизити терапевтичну дозу і запобігти побічним реакціям;

3) зниження ризику виникнення подразнення слизової оболонки шлунка за рахунок відсутності її контакту з основою гумки жувальної та високими концентраціями АФІ;

4) зручне застосування без вживання води;

5) відмінні (з високим комплаєнсом) органолептичні властивості;

6) застосування не потребує спеціальних навичок та не травмує слизові оболонки та шкірні покриви;

7) зниження відчуття сухості у роті за рахунок виділення слини під час жування.

Як і будь-яка лікарська фрорма гумка жувальна, крім переваг, має і недоліки [4, 5, 7], зокрема:

1) залежність швидкості вивільнення АФІ з основи від швидкості жування;

2) лікарські речовини швидко зникають 3 поверхні слизової оболонки ротової порожнини за рахунок потрапляння їх в слину і мимовільного ковтання;

3) концентрація лікарського засобу в ротовій порожнині постійно знижується за рахунок розбавляння слиною;

4) лікарська фрорма діє визначений період часу, оскільки її присутність у порожнині рота обмежує приймання їжі та пиття;

5) наявність у складі даної лікарської фрорми таких підсолоджувачів, як сорбіт, може викликати діарею та метеоризм.

Активні фармацевтичні інгредієнти, які входять до складу гумок жувальних, можуть бути включені як в основу, так і в оболонку, якою в таких випадках, спеціально покривають лікарську фрорму. Частка АФІ у готовій композиції може дуже різнитися, але у більшості випадків становить 0,5 - 30,0 \% від маси гумки жувальної [14].
Ступінь вивільнення АФІ із гумок жувальних залежить від багатьох фракторів. Одним із них $є$ гідроорільність активних компонентів. Водорозчинні речовини добре розчиняються в слині та протягом 10-15 хв повністю вивільняються 3 гумки жувальної. Гідрофробні речовини, навпаки, повільно вивільняються 3 основи гумки жувальної і потребують використання додаткових компонентів для отримання задовільного профрілю розчинення [4]. Крім того, на швидкість вивільнення активних речовин із гумок жувальних вагомо впливають такі індивідуальні особливості окремих людей, як швидкість, частота й інтенсивність жувальних рухів. Європейська Фармакопея рекомендує здійснювати 60 жувальних рухів за хвилину для відповідного вивільнення активних компонентів. Але кількість необхідних жувальних рухів залежить також від часу перебування гумки жувальної в ротовій порожнині. У клінічних випробуваннях такий час складає 30 хв [15].

Для виробництва гумок жувальних лікувальних сьогодні використовують АФІ як синтетичного, так і природного походження. Із синтетичних субстанцій це анальгін, кофеїн, кальцію карбонат, хлоргексидин, нікотин, ксилітол, диметилгідринат гідрохлорид, хлорфеніламін малеат, домперидон малеат, ондансетрону гідрохлорид дигідрат, аскорбінову кислоту та ін. [6, 7, 16-20]. Серед АФІ природного походження - екстракти чаю, імбиру, алое [21-23].

Крім АФІ, до складу гумок жувальних входять не розчинні у воді основи (еластомери), емульгатори, наповнювачі, воски, антиоксиданти, пластифікатори, підсолоджувачі та смакові добавки [23-25].

Еластомери складають основну частину гумок жувальних та забезпечують їх текстуру та еластичність. Для цього використовують природні та синтетичні каучуки без смаку та запаху. До природних еластомерів належать природні каучуки (згущений або не згущений латекс), а також різноманітні природні смоли та їх композиції. 3 синтетичних еластомерів використовують бутадієн-стиролову гуму, поліізобутилен, полівініловий спирт, поліізопрен, полібутадієн. Кількість основи, яка буде використана в гумці жувальній, залежить від таких різних чинників, як тип основи, консистенція гумки жувальної та наявність інших компонентів, що використовуються в композиції для отримання кінцевого продукту. В загальному, основа гумки жувальної може складати 5-94 \% від маси кінцевої композиції, але у більшості випадків вміст основи складає 15-45 \% [26].

Для одержання гумки жувальної 3 дисренгідраміном як жувальну основу використали зеїн із зерен кукурудзи. Гумка жувальна на основі зеїну мала переваги над гумкою жувальною на синтетичних еластомерах. Крім того, зеїн має перевагу над іншими синтетичними полімерами - він біорозщеплюється [27].

3 метою пом'якшення гумової основи до складу гумок жувальних можуть вводити еластомерні розчинники. До них належать такі терпенові смоли, як

ISSN 2312-0967. Pharmaceutical review. 2018. № 1 
полімери альфа- та бета- піненів. Крім терпенових смол, також використовують різноманітні гідрогенізовані, димеризовані або полімеризовані смоли. Еластомерні розчинники можуть бути використані в кількостях від 5,0 до 75,0 \%, від маси основи гумки жувальної [28].

Для надання основам необхідних консистентних властивостей використовують також пластифрікатори. В якості пластифрікаторів в технології гумок жувальних використовують ланолін, пальмітинову, олеїнову, стеаринову кислоти, стеарат натрію, гліцерин, синтетичні воски, гідрогенізовані рослинні олії, пропіленгліколь. Вміст пластифрікаторів у гумці жувальній може становити від 0,5 до 15,0 \% [14].

3 метою забезпечення необхідної оптимальної маси та розміру гумок жувальних використовують наповнювачі. Вміст наповнювача маже становити до 50 \% від маси гумки жувальної. До найбільш часто використовуваних наповнювачів належать кальцію та магнію карбонат, тальк, гідроксид та алюмінію силікат.

Для забезпечення солодкого смаку гумок жувальних використовують різноманітні підсолоджувачі. Серед природних водорозчинних підсолоджувачів використовують сахарозу, фрруктозу, манозу, глюкозу, інвертний цукор, частково гідролізований крохмаль, стевіозиди, гліцеризид, сорбіт, маніт. Також використовують і такі водорозчинні штучні підсолоджувачі, як натрієві або кальцієві солі сахарину, цикламат натрію та аспартам, вміст яких у гумці жувальній може становити аж до 60 \% від маси готового продукту.

На особливу увагу заслуговує ксиліт - природний підсолоджувач. Використання ксиліту у гумках жувальних не лише покращує їх смак, а також зменшує демінералізацію емалі та пригнічує розвиток карієсу [29].

Крім підсолоджувачів, для корекції смаку гумок жувальних можуть бути використані також ароматизатори. Активно застосовуються як синтетичні, так і натуральні ароматизатори. Вид та кількість ароматизатора в гумці жувальній буде залежати від вихідних органолептичних властивостей активних інгредієнтів. Вміст ароматизатора становить в цілому від 0,1 до 1,0 \% від маси гумки жувальної [28].

Для корекції гіркого смаку у гумці жувальній із нікотином використовували такі підсолоджувачі, як цукор, аспартам, сахарин натрію, стевію, а також ароматизатори зі смаком вишні, малини, евкаліпту, м'яти, банану та тутті-фррутті. Найбільш ефективно гіркий смак нікотину маскували аспартам у поєднанні з ароматизаторами вишні та евкаліпту [13].

3 метою підвищення стабільності і подовження терміну придатності до складу гумок жувальних додають антиоксиданти, зокрема бутильований гідрокситолуол, бутильованний гідроксианізол, пропілгалат в кількості до 0,02 \% від маси композиції гумки жувальної.

Гумки жувальні отримують такими методами:

- традиційним методом - плавлення;
- методом замороження, подрібнення і таблетування;

- методом прямого пресування [2, 8-11, 28].

Традиційний метод / плавлення (Conventional/ Traditional method (Melting)). Суть методу полягає в тому, що компоненти основи гумки жувальної підігрівають до їх розм'якшення або сплавляння, після чого додають АФІ та необхідні допоміжні речовини. В подальшому за допомого роликів гумка жувальна розкочується у тонкі стрічки, охолоджується (застигає) та розрізається на частини необхідних розмірів. Під час охолодження та до моменту упаковування готового продукту необхідно суворо стежити за температурою та вологістю у виробничому приміщенні. Даний метод має декілька суттєвих недоліків пов'язаних із тим, що АФІ вводяться в розплавлену основу, що обмежує використання термолабільних речовин, а підвищений вміст вологи (до 8 \%) у готовому продукті накладає обмеження на використання речовин, чутливих до вологи. Також розплавлену в'язку основу важко дозувати, i, як наслідок, складно отримати лікарську фрорму із точно заданою масою та фрормою [28], що є недоліком цього традиційного методу.

Використовуючи даний метод, автори [30] запропонували склад і технологію гумок жувальних лікувальних $з$ метформіном. Найважливішим завданням було маскування гіркого смаку меторорміну. Це завдання було реалізовано додаванням підсолоджувачів, але випробовувались як різні підсолоджувачі, так і різні технологічні прийоми: звичайний метод тритурації (не був успішним), метод розпилювального сушіння попередньо отриманого розчину меторорміну 3 підсолоджувачами (не був успішним), метод кріофрільної сушки попередньо отриманого розчину метформіну з підсолоджувачами (було досягнуто маскування). Кращими підсолоджувачами було обрано суміш ацесульфраму-ізомальту. Отриману у такий спосіб суміш меторорміну з підсолоджувачами у подальшому змішували з гумовою основою (Minoo Industrial Company, Тегеран, Іран) при температурі $65^{\circ} \mathrm{C}$ і додавали гліцерин, ксиліт та ментол, після чого отриману пасту витримували у морозильній камері $\left(-4^{\circ} \mathrm{C}\right)$ впродовж 2 год. Отримані гумки жувальні 3 метформіном мали добрі органолептичні показники - були ароматними, гладкими і м'якими, легко жувалися та мали належні фрармако-технологічні і аналітичні показники якості.

$€$ досвід використання даного методу для виготовлення гумок жувальних лікувальних з густим екстрактом імбиру [23]. Авторами апробовано чотири різні гумові основи Elvasti, 487, Stick, Fruit C (Gilan Ghoot Company (Rasht, Iран)), які нагрівали до $70{ }^{\circ} \mathrm{C}$ на водяній бані при постійному перемішуванні. До розм'якшених основ додавались підсолоджувачі у вигляді тритурації суміші цукру, мальтиту, ксиліту, глюкозного сиропу, аспартаму і пластифрікатора - гліцерину. Після змішування всіх компонентів темпера-

ISSN 2312-0967. Фармацевтичний часопис. 2018. № 1 
туру понижували до $40{ }^{\circ} \mathrm{C}$ і додавали густий екстракт імбиру. За органолептичними властивостями гумки мали добрий смак без додавання ароматизаторів.

Ці ж гумові основи використано іншою групою вчених при розробці складу і технології гумок з кофеїном [31]. Гумові основи розм'якшували на водяній бані при $60{ }^{\circ} \mathrm{C}$. Кофеїн з аспартамом і ксилітом розтирали і отриману тритурацію розчиняли у глюкозному сиропі 3 гліцерином, отриману суміш вводили у розм'якшену гумову основу при сталій температурі. Потім додавали бажану кількість цукру, ретельно перемішували до одержання однорідної суміші. Наприкінці приготування температуру суміші встановлювали нижче $40{ }^{\circ} \mathrm{C}$, поступово додавали ароматизатор (м'яти перцевої, евкаліпту, вишні, банану, коли та кориці) та змішували.

Метод замороження, подрібнення і таблетування (Freezing, grinding and tableting method). Даний метод, на відміну від традиційного, дозволяє використовувати у рецептурі термолабільні речовини. Основу для гумки жувальної охолоджують до температури, при якій композиція стає досить крихкою та ламкою. Температура охолодження залежить від властивостей компонентів основи і у більшості випадків становить близько $-15{ }^{\circ} \mathrm{C}$. Охолодження можуть проводити за допомогою рідкого азоту, але кращим $є$ використання твердого карбон діоксиду ("сухий лід"), за допомогою якого суміш можна охолоджувати до $-78,5{ }^{\circ} \mathrm{C} .3$ метою попередження злипання частинок при подрібненні до складу композиції можуть додавати кремнію діоксид. Після подрібнення та видалення охолоджуючого агента суміш може бути змішана з такими допоміжними речовинами, як підсолоджувачі, ковзні, змащуючі речовини та інші компоненти, необхідні для таблетування. Змішування зручно проводити у змішувачах 3 використанням псевдозрідженого шару. Таке змішування забезпечує не лише перемішування компонентів, але й частково утворення гранул, що в подальшому полегшує таблетування. Таблетування проводять у звичайний спосіб при ретельному контролі вологості у виробничому приміщенні, оскільки надмірна вологість погіршує текучість матеріалу та підвищує адгезію до пресінструменту $[2,5,28]$. Таким чином, недоліками вказаного методу $€$ необхідність високотехнологічного дорогого обладнання і забезпечення визначеного контрольованого рівня вологості у приміщенні.

Метод прямого пресування (Direct compression method). Одержання гумок жувальних методом прямого пресування має ряд переваг порівняно з іншими методами і мало відрізняється від одержання таблеток у такий же спосіб. На фрармацевтичному ринку існують спеціальні композиції, які дозволяють одержувати гумки жувальні шляхом змішування всіх компонентів та подальшого пресування отриманої композиції на звичайних таблетних машинах. Саме такою композицією $€$ Health in gum ${ }^{\circledR}$ (Cafosa, Іспанія). Такі композиції є поєднанням поліолів (цукрів) із жувальною основою. Завдяки текучості порошкової маси вони зручні у використанні. Авторами [19] були визначені фрармако-технологічні показники порошкової мacи Health in gum ${ }^{\circledR}$ (Cafosa, Іспанія), а саме: насипна густина - 0,66 0 0,06 г/мл, насипна густина після усадки - 0,73 \pm 0,07 г/мл, коефріцієнт Гауснера -

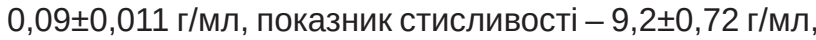
кут природного укосу $-30,70 \pm 1,02^{\circ}$.

Після змішування даних композицій з АФІ, смаковими добавками, змащуючими та ковзними речовинами суміш $є$ придатною для подальшого прямого пресування. Певні обмеження накладає лише те, що необхідно дотримуватись чіткого співвідношення між кількістю основи та кількістю АФІ. Для досягнення оптимальних жувальних властивостей вміст Health in gum® у гумці жувальній має складати 80 - 85 \% від маси всіх компонентів незалежно від кількості АФІ. Таким чином, із збільшення кількості АФІ в гумці жувальній виникає необхідність збільшувати середню масу і розмір жувальної гумки. Одержані із використанням даних композицій гумки жувальні краще вивільняють АФІ 3 основи за рахунок меншого їх зв'язування, а зовні самі гумки можуть нагадувати таблетки [32-35].

Методом прямого пресування з використанням обладнання, яке застосовують для виробництва таблеток, було отримано гумки жувальні лікувальні з цетиризином [36]. Леткий рідкий ароматизатор повільно додавали до порошку гумової основи Health in gum ${ }^{\circledR}$ (Cafosa, Іспанія), яка неперервно «перетікала» у спеціальному змішувачі для в'язких речовин (Sigma blade mixer) постійно перемішуючись та гомогенізуючись. Отриману ароматизовану гумову основу просівали і неперевно продовжували перемішувати послідовно додаючи просіяні АФІ, антиагрегант - очищений тальк (Luzenac $\left.{ }^{\circledR} U \mathrm{M}\right)$ і підсолоджувач - аспартам, магній стеарат (лубрикант) і колоїдний силіцій діоксид (Aerosil ${ }^{\circledR}$ 200) як глідант. Для забезпечення м'якої консистенції готової гумки додавали соєвий лецитин як пластифікатор і титану діоксид для забезпечення білого кольору гумки. Отриману суміш піддавали прямому пресуванню.

Таку ж гумову основу було використано при розробці гумок жувальних лікувальних $з$ домперідоном малеатом [19]. Від попередньої технології застосована в [19] різнилась послідовністю змішування компонентів. Спочатку пропонується отримати ароматизовану АФІ, просіяти іїі і додати, при постійному перемішуванні, до просіяної гумової основи. Потім до отриманої суміші додавати антиагреганти, підсолоджувачі, лубриканти і соєвий лецитин як пластиорікатор.

Покриття гумок жувальних оболонками може здійснюватись 3 різною метою: підвищення вологостійкості, збільшення механічної міцності, покращення смаку, зменшення ступеня прилипання до зовніш-

ISSN 2312-0967. Pharmaceutical review. 2018. № 1 
ніх поверхонь та досягнення необхідного профрілю вивільнення АФІ. Покриття можна наносити як плівку 3 полімерів, воску, підсолоджувачів, ароматизаторів або як товстий шар цукру чи цукрозамінників. Так, при одержанні гумок жувальних методом плавлення покриття наноситься у вигляді тонкоподрібненого цукру або його замінників. Щоб порошок не осипався із гумок жувальних їх попередньо занурюють у підігрітий розчин гліцерину на одну хвилину, після чого наносять цукор. Таке покриття дозволяє поліпшити смак та попередити злипання гумок жувальних [4, 13, 15 ].

У процесі розробки складу і технології гумок вивчають загальноприйняті фармако-технологічні показники для порошків (насипна густина, густина після усадки, насипний об'єм, показник стисливості і коефіцієнт Гауснера, кут природного укосу, швидкість течії через насадку, плинність як сукупна характеристика) і твердих лікарських фрорм (зовнішній вигляд, розмір, фрорма, товщина і діаметр, стираність, стійкість до роздавлювання, втрата в масі при висушуванні, середня маса, однорідність маси, розчинення).

Особливим $€$ дослідження гумок за тестом «Розчинення», оскільки власне розчинення лікарської форми не відбувається. Прилад, який застосовують для виконання даного тесту, має спеціальну будову [37]. $€$ повідомлення про дослідження вивільнення АФІ з гумки шляхом жувального дослідження in vivo на добровольцях [36]. Кожна особа-доброволець жувала одну дозу гумки строго визначений час - 1, 2, 5, 10 або 15 хв. Після визначеного періоду жування гумки аналізували на залишковий вміст АФІ, після чого за різницею вмісту і залишкового вмісту визначали «кількість АФІ, вивільненого при жуванні».

Специфічними показниками для даної лікарської форми є текстура і морфологічна характеристика поверхні та показники, які характеризують міцність гумки (остаточна міцність до розриву, модуль пружності або модуль Юнга, поведінка при розтягуванні). Дослідження морфологічних особливостей поверхні гумок здійснюють методом електронної мікроскопії. Отримані при цьому результати сукупно із закономірностями зміни показника «текстура» залежно від складу дозволяють обрати оптимальне співвідношення базових компонентів гумок жувальних лікувальних [19]. Текстура $є$ дуже важливою якісною характеристикою гумок. Текстурний аналіз дозволяє вивчити поведінку готової лікарської фрорми в процесі застосування, дослідити відчуття, які виникатимуть при її застосуванні. Текстура оцінюється органолептично й інструментально. При інструментальній оцінці показника визначають твердість і адгезивність. Застосовуючи спеціальне обладнання (аналізатор текстури «Brookfield ${ }^{\circledR}$ QTS-25»), яке дає змогу оцінити силу, при якій відбувається розрив гумки, отримують відповідну криву деформації. Наявність негативного піка після точки розриву вказує на адгезивність гумки і її здатність знову сполучатись, що у циклічному режимі жування позитивно впливає на вивільнення АФІ [36].

При виборі ароматизаторів, кількості підсолоджувачів, еластомерів і пластисрікаторів у процесі розробки складу гумок жувальних лікувальних вирішальними $€$ саме органолептичні показники (смак в загальному, солодкість, тривалість аромату, м'якість/ твердість при жуванні і здатність до жування, здатність/нездатність прилипати до зубів, об'ємність маси гумки, здатність маскувати гіркий смак АФІ).

В окремих дослідженнях розробки складу і технології гумок визначають рівень букального проникнення АФІ $[19,36]$ in vitro. Дослідження виконували із застосуванням статичної дифузійної комірки (Hanson Research ${ }^{\circledR}$ Variomag Telemodule 40s Franz) і мембрани зі слизової оболонки внутрішньої поверхні щоки кози або свині. Донорна комірка імітує умови порожними рота (фоссратний буфрерний розчин, який має pH слини $(6,8))$, а приймальна комірка - кров (фросфатний бусрерний розчин 3 рН крові $(7,4))$. АФІ $з$ певною концентрацією поміщають у донорну комірку і через визначені інтервали часу відбирають проби 3 приймальної комірки, розраховуючи відсоток проникнення.

Контроль якості гумок жувальних лікувальних проводиться за такими показниками: опис, середня маса, відхилення від середньої маси, однорідність вмісту (якщо вміст діючої речовини менше 2 мг або менше 2 \% від загальної маси), стійкість до роздавлювання, розчинення, для визначення якого має бути проведений «Тест «Розчинення» для гумок жувальних лікувальних» (2.9.25), кількісне визначення [37]. Для випробування препарату in vitro сконструйовано спеціальний пристрій, який імітує жувальні рухи та дозволяє визначити швидкість та ступінь вивільнення активних компонентів у буферний розчин [11, 28, $37,38]$, опис і фрармакопейні вимоги до якого детально наведено в [37]. При виробництві, пакуванні, зберіганні та реалізації гумок жувальних мають бути вжиті належні заходи для забезпечення відповідної мікробіологічної чистоти. Відповідні рекомендації наведено у статті «Мікробіологічна чистота нестерильних лікарських засобів і субстанцій для фрармацевтичного застосування (5.1.4) [37].

Висновок. Гумка жувальна лікувальна - це мобільна система доставки ліків, яка містить один або кілька активних інгредієнтів, що вивільняються шляхом жування. Розглянуто методи та особливості технології, фрармако-технологічні показники і показники якості гумок жувальних лікувальних. Дана лікарська форма має переваги порівняно $з$ традиційними системами доставки ліків, характеризується високим комплаєнсом. Серед трьох відомих методів отримання гумок, за рахунок появи готових основ промислового виробництва, все більшого застосування набуває метод прямого пресування.

ISSN 2312-0967. Фармацевтичний часопис. 2018. № 1 


\title{
РЕЗИНКИ ЖЕВАТЕЛЬНЫЕ ЛЕЧЕБНЫЕ: НАЗНАЧЕНИЕ, ТЕХНОЛОГИЯ И АНАЛИЗ
}

\author{
В. Н. Коваль ${ }^{1}$, А. И. Денис ${ }^{2}$, Т. А. Грошовый², Л. В. Вронска \\ Винницкий национальный медицинский университет имени Н. И. Пирогова ${ }^{1}$ \\ ГВУЗ «Тернопольский государственный медицинский университет имени И. Я. Горбачевского Мз \\ Украины»² \\ Koval_vm@ukr.net
}

Цель работы. Анализ и систематизация данных литературы по назначению и классификации резинок жевательных лечебных, их технологии, методов исследования и показателей качества.

Материалы и методы. В работе использованы методы информационного поиска, анализа данных литературы о лекарственной фрорме - резинка жевательная лечебная.

Результаты и обсуждение. Резинка жевательная лечебная является удобной системой доставки лекарственного средства и может обеспечивать высокую комплаентность пациента. Для изготовления резинки жевательной лечебной используют метод плавления; метод замораживания, измельчения и таблетирования; метод прямого прессования. Фармакопейными показателями качества резинок являются описание, идентификация, средняя масса, однородность массы, однородность содержания, растворение, микробиологическая чистота, количественное определение. В процессе разработки состава и технологии резинок, набор фрармако-технологических показателей и методик испытаний существенно отличается от фрармакопейных и включает определение многочисленных органолептических свойств, изучение текстуры инструментальными методами.

Выводы. Резинка жевательная лечебная - мобильная система доставки лекарств, которая содержит один или несколько активных ингредиентов, высвобождающихся путем жевания. Рассмотрены методы и особенности технологии, срармако-технологические показатели и показатели качества резинок жевательных лечебных. Данная лекарственная фрорма имеет преимущества по сравнению с традиционными системами доставки лекарств, характеризуется высоким комплаенсом. Среди трех известных методов получения резинок, за счет появления готовых основ промышленного производства, все большее применение приобретает метод прямого прессования.

Ключевые слова: резинки жевательные лечебные; назначение; преимущества; недостатки; технология; фрармакотехнологические показатели; показатели качества.

\section{MEDICATED CHEWING GUMS: PRESCRIPTION, TECHNOLOGY AND ANALYSIS}

\author{
V. M. Koval, ${ }^{1}$ A. I. Denys ${ }^{2}$, T. A. Hroshovyi ${ }^{2}$, L. V. Vronska ${ }^{2}$ \\ M. Pyrohov Vinnytsia National Medical University ${ }^{1}$ \\ I. Horbachevsky Ternopil State Medical University² \\ Koval_vm@ukr.net
}

The aim of the work. Analyzing and systematizing the literature on the purpose and classification of medicated chewing gums, their technology, research methods and quality indicators.

Materials and Methods. The methods of information retrieval, analysis of the literature on the medical form - medicated chewing gum, were used in the study.

Results and Discussion. The medicated chewing gum is a convenient drug delivery system; it provides a high patient compliance. Three methods are used in the production of chewing gums: the traditional method (melting); the method of freezing, grinding and tableting; the direct compression method. Pharmacopoeial parameters of the gums quality are: description, identification, average mass, uniformity of mass, uniformity of content, dissolution, microbiological purity, quantitative determination. In the course of the development of composition and technology of medicated chewing gums, the set of pharmaco-technological indicators and test methods is significantly different from pharmacopeial one and comprises the definition of numerous organoleptic properties, the study of texture by instrumental methods.

Conclusions. The medicated chewing gums are a mobile drug delivery system that contains one or more active ingredients that are released by chewing. The methods and features of technology, pharmaco-technological indicators and quality indicators of the medicated chewing gum are presented. This dosage form has advantages over traditional drug delivery systems; is characterized by high compliance. Among the three established methods of the gums producing, the direct compression method is becoming ever more popular because of the development of ready chewing bases of industrial production.

Key words: medicated chewing gums; purpose; advantages; disadvantages; technology; pharmaco-technological indicators; quality indicators.

ISSN 2312-0967. Pharmaceutical review. 2018. № 1 


\section{Список літератури}

1. Фармацевтична енциклопедія [Електронний ресурс]. - Режим доступу: https://www.pharmencyclopedia.com.ua 2. Bhaskar D. Ingole Chewing gum: A mobile drug delivery system / Bhaskar D. Ingole, Amit S. Daga, Unmesh M. Joshi [et al.] // Int. J. Pharm. Sci. Rev. Res. - 2012. Iss.18. - P. 106-114.

3. Medicated chewing gum - A 21st century drug delivery system / A. G Gadhavi, B. N. Patel, D. M. Patel, C. N. Patel // Int. J. Pharm. Sci Res. - 2011. - Iss. 2. -P. 1961-1974.

4. Jadhav A. V. A Comprehensive review on: medicated chewing gum / A. V. Jadhav, S. K. Mohite // Journal of Current Pharma Research. - 2014. - Iss. 4 (3). - P. 12151224.

5. Chewing gum: a modern era of drug delivery / P. Savaliy, A. Karigar, M. V. Ramana [et al.] // International Research Journal of Pharmacy. -2011. - Iss.10. - P. 7-12.

6. Mehta F. Formulation and characterization of medicated chewing gum delivery of Diphenhydramine Hydrochloride / F. Mehta, C. Kartikayen, P. Trivedi // Der Pharmacia Sinica. - 2011. - Iss.1. - P. 182-193.

7. Insulin chewing gum: Need of the day for diabetic patients / U. V. Mateti, N. Adla, T. Rajakannan, R. Valakkathala // International Journal of Pharmaceutical Investigation. - 2011.- Iss. 3. - P. 131-134.

8. Biswal P. K. An updated review on medicated chewing gum / P. K. Biswal, Anantkumar //International Journal of Advanced in Pharmacy, Biology and Chemistry. - 2013. Iss.2. - P. 351-359.

9. Chandran S. Development and characterization of medicated chewing gum containing Indomethacin IP / S. Chandran, Mrs. Neethu, K. V. Vipin // International Journal of Applied Pharmaceutical and Biological Research. - 2016. - Iss.1 (2). - P. 150-157.

10. Chandran S. Formulation and evaluation of medicated chewing gums containing Methyl Prednisolone IP/ S. Chandran, Mr.Srijeesh Ravi, Mr. Vipin K. V. Ann Rose Augusthy // Int. J. Chem. Tech Res. -2014. - Iss.11- P. 4810-4816. 11. Holistic Concept on Medicated chewing gum // P. Vaishya, Evneet K. Bhatia, A. Mishra [et al.] // International Journal of Pharmaceutical \& Biological Archives. 2014. - Iss. 4. - P. 30-39.

12. Kamimori The rate of absorption and relativebio availability of caffe in eadministere din chewing gum versuscapsulestonormalhealthyvolunteers / Gary H. Kamimori, Chetan S. Karyekar, R. Otterstetter [et al.] // International Journal of Pharmaceutics. - 2002. - Iss. 234. - P. 159-167. 13. Aslani A. Design formulation and evaluation of nicotine chewing gum / A. Aslani, R. Sahar // Advanced Biomedical Research. - 2012. - Iss. 4. - P. 1-6.

14. Mucosal drug delivery / Mohan A. Ughade, Suraj R. Wasankar, Abhishek D. Deshmukh [et al.] // Asian J. Res. Pharm. Sci. - 2012.- V. 2. Iss. 4. - P. 150-159.

15. Aslani A. Medicated chewing gum, a novel drug delivery system / A. Aslani, F. Rostami // Journal of Research in Medical Sciences. - 2015. - Iss. 4 - P. 403-411.

16. Mehta F. Formulation and texture characterization of medicated chewing gum delivery of Dimenhydrinate Hydrochloride/ F. Mehta, P. Trivedi // Der Pharmacia Lettre. - 2011. - Iss. 3 (6) - P. 179-192.
17. Koppula. Rajitha Formulation and evaluation of medicated chewing gum of chlorpheniramine maleate by melting method/ Koppula. Rajitha, Yamsani. Madhusudhan Rao // World Journal of Pharmacy and Pharmaceutical Sciences. - 2016. - Iss. 5. - P. 1322-1329.

18. Bioequivalence of two different nicotine chewing gum formulations of two different strengths (2 mgand $4 \mathrm{mg}$ ) in indian healthy adult human male smoker subjects / M. Garg, R. Naidu, K. Iyer [et al.] // Journal of Bioequivalence \& Bioavailability. - 2016. - Vol. 8 (2). - P. 74-79.

19. Paradkar M. Formulation development and evaluation of medicated chewing gum of anti-emetic drug / M. Paradkar, B. Gajra, B. Patel // Saudi Pharmaceutical Journal. 2016. - 19. Vol. 24, Iss. 2. - P. 153-164.

20. Vaishya P. Formulation and evaluation of medicated chewing gum of Ondancetron $\mathrm{HCl}$ for chemotherapy inducednausea and vomiting / P. Vaishya, A. Mishra, A. Pathak // Der Pharmacia Lettre. - 2015. - Iss.7 (5). - P. 80-86.

21. Aslani A. Design, formulation and evaluation of green tea chewing gum / A. Aslani, A. Ghannadi, Z. Khalafi // Adv. Biomed. Res. - 2014. - Vol. 3. - P. 142.

22. Aslani A. Design, formulation and evaluation of Aloe vera chewing gum / A. Aslani, A. Ghannadi, R. Raddanipour // Adv. Biomed. Res. - 2015. - Vol. 4. - P. 175.

23. Aslani A. Design, formulation, and evaluation of ginger medicated chewing gum / A. Aslani, A. Ghannadi, F. Rostami // Adv. Biomed. Res. - 2016. - Vol. 5. - P. 130.

24. Aslani A. Design, Formulation and Evaluation of Medicinal Chewing Gum by the Extract of Salvadorapersica L. I A. Aslani, A. Ghannadi, Sh. Mortazavietal. // Life Science Journal. -2013. -Iss.4 . - P. 47-55.

25. Hitesh J. Medicated chewing gum: a novel oral drug delivery / J. Hitesh, Sh. Mansi, Sh. Bhoomi [et al.] // International Journal of Drug Formulation Research. - 2010. Iss.1 -P. 80-96.

26. Nagasamy V. D Medicated chewing gums - A review / V. D. Nagasamy S. T. Pallavi, M. Sougata [et al.] // Int. J. Pharma Sci. - 2014. - Iss.3. - P. 581-586.

27. Mehta F. Formulation and characterization of biodegradable medicated chewing gum delivery system for motion sicknessusing corn zeinas gum former/ F. F. Mehta, P. Trivedi // Tropical Journal of Pharmaceutical Research. - 2015. - Iss. 14(5) - P. 753-760.

28. Kinjal R. Shahetal medicated chewing gum a mobile oral drug delivery system / Kinjal R. Shahetal // Int. J. Pharm. Tech. Res. - 2014. - Vol. 6(1). - P. 35-48.

29. Navya M. Chewing gum as a drug delivery system / M. Navya, N. Ramarao // International Journal of Pharma and Bio Sciences. - 2014. Vol. - 5(4). - P. 148-161.

30. Mostafavi S. A. Formulation development of metformin chewing gum with bitter taste masking / S. A. Mostafavi, J. Varshosaz, S. Arabian / Adv. Biomed. Res. - 2014. Vol. 3. - P. 92.

31. Aslani A. Design, formulation and evaluation of caffeine chewing gum / A. Aslani, F. Jalilian // Adv. Biomed. Res. 2013. - Vol. 2. - P. 72.

32. Ruban O.A. Technological peculiarities for obtaining of medicated chewing gums / O. A. Ruban, Ju. S.Masliy // Вісник фрармації. - 2014. - 4 (80). - С. 32-34.

ISSN 2312-0967. Фармацевтичний часопис. 2018. № 1 
33. Koppula R. Medicated chewing gums - a modern era / R. Koppula, F. Begum, R. Sunil [et al.] // Int. J. Pharm. Sci. Rev. Res. - 2015. - Vol. 30(2), - P. 47-56.

34. Cafosa. Health in gum [Електронний ресурс]. - Режим доступу: http://www.cafosa.com/EN_Health_in_Gum

35. Witec. Основа для фрармацевтической жвачки [Електронний ресурс]. - Режим доступу: http://www.witec.com.ua/pharmaceutical_raw_material/basis-pharmaceutical-chewing/

36. Chaudhary S. A. Directly compressible medicated chewing gum formulation for quick relief from common cold / S. A. Chaudhary, A. F. Shahiwala // Int. J. Pharm. Investig.
- 2012. - Vol. 2(3). - P. 123-133.

37. Державна Фармакопея України : в 3 т. / Державне підприємство "Український науковий фрармакопейний центр якості лікарських засобів". - 2-е вид. - Харків : Державне підприємство "Український науковий срармакопейний центр якості лікарських засобів", 2015. - T. 1. - 1128 c.

38. Daharwal S. J. Designing and optimization of Modified Dissolution Apparatus for Evaluation of Medicated Chewing Gumof Ambroxol HCl / S. J. Daharwal, Veena Devi Thakur, Shikha Shrivastava [et al.] // Asian J. Pharm. Res. - 2013. - Vol. 3, Iss. 3. - P. 141-143.

\section{References}

1. Pharmaceutical Encyclopedia. Available from: https:// www.pharmencyclopedia.com.ua

2. Bhaskar D. Ingole, Amit S. Daga, Unmesh M. Joshi, Kailash R. Biyani, Chewing Gum: A Mobile Drug Delivery System. Int. J. Pharm. Sci. Rev. Res., 2012: 14(2):106-14.

3. Gadhavi AG, Patel BN, Patel DM, Patel CN. Medicated chewing gum - A 21st century drug delivery system. Int J Pharm Sci Res. 2011:2:1961-74.

4. Jadhav AV, Mohite SK. A. Comprehensive Review On: Medicated Chewing Gum. Journal of Current Pharma Research. 2014:4:1215-24.

5. Savaliy P, Karigar A, Ramana MV. Chewing gum: a modern era of drug delivery. International Research Journal of Pharmacy. 2011:2(10):7-12.

6. Mehta F, Kartikayen C, Trive P. Formulation and characterization of medicated chewing gum delivery of Diphenhydramine Hydrochloride. Der Pharmacia Sinica. 2011:2(1):182-93

7. Mateti UV, Adla N, Rajakannan T, Valakkathala R. Insulin chewing gum: Need of the day for diabetic patients. International Journal of Pharmaceutical Investigation. 2011:3:1314.

8. Biswal PK, Anantkumar. An updated review on medicated chewing gum. International Journal of Advanced in Pharmacy, Biology and Chemistry. 2013: 2:351-9.

9. Chandran S, Mrs. Neethu, Vipin KV. Development and characterization of medicated chewing gum containing Indomethacin IP. International journal of Applied Pharmaceutical and Biological Research. 2016:1(2):150-7.

10. Chandran S, Mr.Srijeesh Ravi, Mr.Vipin KV, Ann Rose Augusthy. Formulation and evaluation of medicated chewing gums containing Methyl Prednisolone IP. Int.J. ChemTech Res. 2014:11:4810-16.

11. Prabhanshu Vaishy, Evneet K. Bhatia, Ashwani Mishra et al. A Holistic Concept on Medicated Chewing Gum. International Journal of Pharmaceutical \& Biological Archives. 2014:4:30-9.

12. Gary H. Kamimori, Chetan S. Karyekar, Otterstetter R. The rate of absorption and relativebio availability of caffe in eadministere din chewing gum versuscapsules tonorma healthy volunteers. International Journal of Pharmaceutics. 2002:234:159-67.

13. Aslani A, Sahar R. Design formulation and evaluation of nicotine chewing gum. Advanced Biomedical Research. 2012:4:1-6.

14. Mohan A Ughade, Suraj R. Wasankar, Abhishek D. Deshmukh et al. Medicated Chewing Gum: Modern Approach to Mucosal Drug Delivery. Asian J. Res. Pharm. Sci. 2012:4:150-9.

15. Aslani A, Rostami F. Medicated chewing gum, a novel drug delivery system. Journal of Research in Medical Sciences. 2015:4:403-11.

16. Mehta F, Trivedi P. Formulation and texture characterization of medicated chewing gum delivery of Dimenhydrinate Hydrochloride / Der Pharmacia Lettre. 2011:3(6):17992.

17. Koppula. Rajitha, Yamsani. Madhusudhan Rao Formulation and evaluation of medicated chewing gum of chlorpheniramine maleate bymelting method. World Journal of Pharmacy and Pharmaceutical Sciences. 2016:5(5):13229.

18. Garg M, Naidu R, Iyer K. Bioequivalence of two different nicotine chewing gum formulations of two different strengths (2 mgand $4 \mathrm{mg}$ ) in indian healthy adult human male smoker subjects. Journal of Bioequivalence \& Bioavailability. 2016:8(2):74-9.

19. 19. Paradkar M, 19. Gajra B, 19. Patel B. Formulation development and evaluation of medicated chewing gum of antiemetic drug 19. Saudi Pharmaceutical Journal. 2016: 19. 24(2):153-64.

20. Vaishya P, Mishra A, Pathak A. Formulation and evaluation of medicated chewing gum of Ondancetron $\mathrm{HCl}$ for chemotherapy inducednausea and vomiting. Der Pharmacia Lettre. 2015:7(5): 80-6.

21. Aslani A, Ghannadi A, Khalafi Z Design. Formulation and evaluation of green tea chewing gum. Adv. Biomed. Res. 2014:3:142.

22. Aslani A, Ghannadi A, Raddanipour R Design, Formulation and evaluation of Aloe vera chewing gum. Adv. Biomed. Res. 2015:4:175.

23. Aslani A, Ghannadi , Rostami F. Design. Formulation, and evaluation of ginger medicated chewing gum. Adv. Biomed. Res. 2016:5:130.

24. Aslani A, Ghannadi A, Mortazavietal Sh. Design, Formulation and Evaluation of Medicinal Chewing Gum by the Extract of Salvadorapersica L.. Life Science Journal. 2013:4:47-55.

25. Hitesh J, Mansi Sh, Bhoomi Sh et al. Medicated Chewing Gum: A Novel Oral Drug Delivery International Journal of Drug Formulation Research. 2010:1:80-96.

ISSN 2312-0967. Pharmaceutical review. 2018. № 1 
26. Nagasamy VD, Pallavi ST, Sougata M et al. Medicated chewing gums - A review. Int. J. Pharma Sci. 2014:3:581-6. 27. Mehta F, Trivedi P. Formulation and characterization of biodegradable medicated chewing gum delivery system for motion sicknessusing corn zeinas gum former. Tropical Journal of Pharmaceutical Research. 2015:14(5):753-60.

28. Kinjal R. Shah, Tejal A, Mehta Sh. Medicated Chewing Gum - A Mobile Oral Drug Delivery System. Int. J. PharmTech Res. 2014:6:35-48.

29. Navya M. Ramarao N. Chewing gum as a drug delivery system. International Journal of Pharma and Bio Sciences. 2011:4:148-61.

30. Mostafavi SA, Varshosaz J, Arabian S. Formulation development of metformin chewing gum with bitter taste masking. Adv. Biomed. Res. 2014:3:92.

31. Aslani A, Jalilian F. Design, formulation and evaluation of caffeine chewing gum. Adv. Biomed. Res. 2013:2:72.

32. Ruban OA, Masliy Ju.S. Technological peculiarities for obtaining of medicated chewing gums. News of Pharmacy. 2014:4:32-4.

33. Koppula R, Begum F, Sunil R et al. Medicated Chewing Gums - A Modern Era. Int. J. Pharm. Sci. Rev. Res. 2015:2:47-56.

34. Available from: http://www.cafosa.com/EN_Health_in_Gum 35. Available from: http://www.witec.com.ua/pharmaceutical_raw_material/basis-pharmaceutical-chewing/

36. Chaudhary SA, Shahiwala AF. Directly compressible medicated chewing gum formulation for quick relief from common cold. Int. J. Pharm. Investig. 2012:2(3):123-33.

37. State Pharmacopoeia of Ukraine [Державна фрармакопея України] Kharkiv : State Enterprise " Ukrainian Scientific Pharmacopoeia Center for the Medicines Quality"; 2015. Ukrainian.

38. Daharwal SJ, Thakur VD, Shrivastava Sh. Designing and optimization of Modified Dissolution Apparatus for Evaluation of Medicated Chewing Gumof Ambroxol $\mathrm{HCl}$. Asian J. Pharm. Res. 2013:3(3):141-3.

Отримано 26.12.2017 